\begin{tabular}{|c|c|c|c|c|}
\hline Share: Social Work Jurnal & VOLUME: 10 & NOMOR: 1 & HALAMAN: $109-117$ & $\begin{array}{c}\text { ISSN: 2339-0042 (p) } \\
\text { ISSN: 2528-1577 }(e) \\
\text { DOI: 10.24198/share.v10i1.26896 }\end{array}$ \\
\hline
\end{tabular}

\title{
UPAYA PREVENTIF KONFLIK PENGGUSURAN LAHAN
}

\author{
Oleh, \\ Soni Akhmad Nulhaqim' Eva Nuriyah Hidayat², M. Fedryansyah³ \\ 1, 2, ${ }^{3}$ Kajian Konflik Pusat Studi CSR, Kewirausahaan Sosial, dan Pemberdayaan Masyarakat FISIP - UNPAD \\ Email: soni.nulhaqim@unpad.ac.id
}

\begin{abstract}
ABSTRAK
Indonesia giat melakukan pembangunan insfrastruktur, khususnya sarana yang mendukung mobilitas warga masyarakat, seperti jalan-jalan tol dan revitalisasi jalur kereta apiSebagai dampak dari pembangunan yang dilakukan pemerintah, penggusuran lahan merupakan permasalahan yang menimbulkan konflik dalam masyarakat. Pembangunan infrastruktur, seperti pembangunan jalan tol dan revitalisasi jalur-jalur kereta api sudah pasti membutuhkan lahan luas, yang seringkali bersinggungan dengan pemilik atau yang tinggal di lahan tergusur tersebut. Faktor penyebab terjadinya konflik dalam penggusuran lahan ini masyarakat merasa dirugikan dan merasa tidak mendapat perlindungan, karena tidak sedikit penggusuran dilakukan dengan paksaan. Komunikasi dan sosialisasi yang minim dengan pemilik lahan juga merupakan faktor yang menimbulkan konflik. Upaya-upaya preventif untuk mencegah terjadinya konflik dalam penggusuran lahan ini semestinya dapat dilakukan, di antaranya dengan komunikasi dan sosialisasi kegiatan pembangunan, membangun mufakat, penggantian ganti rugi yang layak, membangun partisipasi masyarakat dan relokasi yang layak. Namun demikian, dengan alasan kecepatan pembangunan yang segera, maka seringkali masyarakat menjadi korban dari penggusuran lahan ini.
\end{abstract}

Kata kunci: konflik, preventif, penggusuran lahan

\section{ABSTRACT}

Indonesia is actively developing infrastructure, particularly facilities that support the mobility of citizens, such as toll roads and the revitalization of railways. As a result of the development carried out by the government, land clearing is a problem that causes conflict in the community. Infrastructure development, such as the construction of toll roads and the revitalization of railways, certainly requires large areas of land, which often intersect with owners or those who live in the evicted land. The factor causing the conflict in the land eviction is that the community feels aggrieved and feels they do not receive protection, because many evictions were carried out by force. Minimal communication and outreach with land owners is also a factor in causing conflict. Preventive efforts to prevent conflicts in land eviction should be carried out, including communication and dissemination of development activities, building consensus, appropriate compensation, building community participation and appropriate relocation. However, due to the speed of development that is fast, people often become victims of this land eviction.

Key words: conflict, preventive, land eviction

\section{PENDAHULUAN}

Pembangunan di Indonesia pada saat ini menganut semangat percepatan pembangunan, dimana pemerintah mengadakan serangkaian upaya dalam mendorong investasi dalam segala sektor terkait infrastruktur. Namun penyediaan infrastruktur ini mendapat beberapa kendala 
mulai dari tahapan persiapan sampai pada implementasinya. Salah satu kendala yang muncul adalah pengadaan tanah, meskipun pemerintah telah menerbitkan UndangUndang No. 2 Tahun 2012 untuk percepatan proses pengadaan tanah untuk kepentingan umum, dan peraturan-peraturan turunannya yang telah direvisi sesuai dengan kebutuhan pembangunan.

Permasalahan pengadaan tanah ini menyebabkan berbagai persoalan diantaranya penggusuran lahan. Penggusuran dianggap sebagai suatu hal yang negatif karena identik dengan tindakan pemaksaan, pengusiran, konflik dan keributan. Berbagai kasus penggusuran lahan selalu berakhir dengan konflik antara pemilik lahan dengan pemerintah atau yang akan melakukan pembangunan.

Penggusuran yaitu pengusiran paksa baik secara langsung maupun secara tidak langsung yang dilakukan pemerintah setempat terhadap penduduk yang menggunakan sumber daya lahan untuk keperluan hunian maupun usaha. Penggusuran terjadi di wilayah urban karena keterbatasan dan mahalnya lahan. Sedangkan di wilayah rural penggusuran biasanya terjadi atas nama pembangunan proyek prasarana besar seperti misalnya bendungan.

Di kota besar, penggusuran kampung miskin menyebabkan rusaknya jaringan sosial antar tetangga dan keluarga, merusak kestabilan kehidupan keseharian seperti bekerja dan bersekolah serta melenyapkan aset hunian. Penggusuran adalah pelanggaran hak tinggal dan hak memiliki penghidupan.

Bila melihat konvesi internasional hak ekonomi sosial dan budaya, Perserikatan Bangsa-Bangsa sudah menganggap penggusuran ini sebagai pelanggaran atau kejahatan hak asasi manusia yang serius. Dikatakan sebagai kejahatan HAM serius karena dalam proses penggusuran terjadi pelanggaran HAM yang dilakukan secara berlapis. Tidak hanya perampasan hak atas tanah dan bangunannya, tetapi juga hak asasi kesehatan, hak asasi identitas, bahkan asasi pendidikannya.
Pada dasarnya proses pembangunan infrastruktur dan penegakan hak asasi manusia in bisa berjalan beriringan. Penolakan terhadap relokasi ataupun penggusuran bukan berarti penolakan terhadap pembangunan yang akan dilakukan oleh pemerintah. Penggusuran menimbulkan kemiskinan struktural, karena orang-orang yang dirampas lahannya kebanyakan terjebak dalam jurang kemiskinan. Indonesia seharusnya melihat kembali konvesi internasional hak ekonomi dan sosial budaya, meskipun konvensi ini sudah diratifikasi dengan disahkannya Undang-Undang No. 11 Tahun 2005 oleh DPR dan pemerintah. Namun pada kenyataannya selama ini proses relokasi maupun penggusuran yan dilakukan masih banyak yang belum memperhatikan konvensi internasional tersebut sebagai bahan pertimbangan.

Pemerintah pada saat ini sedang gencar melalukan pembangunan, kemudian didorong lagi dengan pada tahun 2014 Pemerintah telah membentuk Komite Percepatan Penyediaan Infrastruktur Prioritas (KPPIP) untuk memimpin koordinasi percepatan infrastruktur prioritas dan mendorong peningkatan kualitas penyiapan proyek melalui Panduan OBC. Langkah perbaikan ditunjang dengan berkembangnya kapasitas Kementerian PPN / Bappenas dalam memberikan fasilitas penyiapan proyek, serta dilanjutkan oleh PPP Unit di Kementerian Keuangan dengan memberikan Project Development Fund(PDF) dan Transaction Advisory untuk proyek KPBU, sehingga diharapkan agar investor tertarik untuk mendanai proyek. Berbagai kebijakan pembangunan ini bertujuan meningkatkan pertumbuhan ekonomi, namun pemerintah juga harus memperhatikan dampak pembangunan tersebut.

Terkait dengan proses penggusuran, dalam perintah umum kovensi internasional hak ekonomi, sosial, dan budaya sudah ada arahan dalam pelaksanaannya yang tertuang dalam general command nomor 4 tentang hak atas tempat tinggal yang layak dan nomor 7 tentang hak atas tempat tinggal yang layak: pengusiran paksa. Pemberian 
uang ganti rugi yang sesuai dengan nilai tanah atau rumah yang digusur sudah sesuai dengan prinsip HAM. Hal ini karena masalah ganti rugi sebenarnya tidak hanya soal ganti rugi secara fisik, tapi ada banyak hal yang harus diperhatikan dalam ganti rugi atas suatu penggusuran lahan.

Menurut Alghiffari, ada tujuh pertimbangan yang harus dijadikan pedoman dalam pemberian ganti rugi terhadap korban penggusuran, yaitu jaminan legalitas kepemilikan, ketersediaan akan berbagai layanan, keterjangkauan, layak huni, aksesbilitas, lokasi, dan juga kelayakan budaya.Permasalahan diatas menimbulkan konflik yang ada pada masyarakat yang merasa dirugikan atas penggusuran lahan ini. Konflik ini bahkan menjadi konfrontasi baik yang dilakukan secara anarkis oleh masyarakat maupun konfrontasi yang dilakukan di jalur pengadilan dan non pengadilan (arbitrase). Konfrontasi anarkis banyak dilakukan masyarakat karena tidak sedikit penggusuran melibatkan preman bahkan oknum TNI misalnya.

Konflik merupakan fenomena yang selalu melekat dalam kehidupan masyarakat, sebagai realitas yang tidak dapat dihindarkan dan akan selalu dan terus terjadi (Nasikun dalam Nulhaqim, 2017:76). Konflik terjadi baik pada tataran individu maupun tataran kelompok dalam masyarakat (Putra, 2014). Menurut Pasal 1 butir 1 UU No. 7 Tahun 2012 tentang Penanganan Konflik Sosial, dijelaskan bahwa yang dimaksud dengan konflik sosial yaitu perseteruan dan/atau benturan fisik dengan kekerasan antara dua kelompok masyarakat atau lebih yang berlangsung dalam waktu tertentu dan berdampak luas yang mengakibatkan ketidaknyamanan dan disintegrasi sosial sehingga mengganggu stabilitas nasional dan menghambat pembangunan nasional.

Menurut De Dreu dan Gelfand (2007) dalam Putra (2013) konflik merupakan proses yang mulai ketika individu atau kelompok mempersepsi terjadinya perbedaan atau opisisi antara dirinya dengan individu atau kelompok lain mengenai minat dan sumber daya, keyakinan, nilai, atau praktik-praktik lainnya. Konflik penggusuran lahan ini termasuk salah satu konflik agraria. Konflik agraria sendiri merupakan salah satu bentuk konflik yang berkaitan dengan tanah. Pada dasarnya tanah adalah aset yang paling penting dalam kehidupan masyarakat karena tanah adalah sumber kehidupan. Dalam negara agraris tanah merupakan sumber utama dalam berproduksi sehingga di Indonesia dalam hak kepemilikan, hak guna usaha, hak pakai, hak sewa, hak membuka tanah, hak memungut hasil hutan dibatasi dalam Undang-Undang Pokok Agraria. Permasalahan mengenai pertanahan bisa menimbulkan konflik yang berkepanjangan antara orang dengan orang maupun orang dengan badan hukum.

Konflik yang terjadi akibat penggusuran lahan ini sangat diharapkan tidak terjadi dalam masyarakat, karena pembangunan yang direncanakan pemerintah pada dasarnya untuk meningkatkan taraf hidup masyarakatnya. Oleh karena itu diperlukan upaya-upaya preventif untuk mencegah terjadinya konflik tersebut.

Upaya Preventif adalah suatu tindakan pengendalian sosial yang dilakukan untuk dapat mencegah atau juga mengurangi kemungkinan terjadinya hal-hal yang tidak diinginkan di masa mendatang. Tindakan preventif (pencegahan) ini dilakukan manusia, baik itu secara pribadi atau juga berkelompok untuk dapat melindungi diri mereka dari hal buruk yang mungkin dapat terjadi. Pada tulisan ini akan dianalisis beberapa upaya preventif mengatasi permasalahan penggusuran lahan agar tidak terjadi konflik di dalam masyarakat. Dalam analisis ini akan dibahas penyebab terjadinya konflik, masalahmasalah dan bagaimana upaya mencegah terjadinya konflik dalam masyarakat.

\section{METODE PENELITIAN}

Metode penelitian dalam kajian ini yaitu menggunakan metode penelitian kualitatif deskriptif dengan tujuan untuk menganalisis fenomena konflik penggusuran lahan dan upaya-upaya preventif agar tidak terjadi konflik dalam penggusuran lahan. Data 
dalam artikel ini diperoleh melalui teknik studi literatur dan studi penelitian terdahulu.

\section{HASIL DAN PEMBAHASAN}

Pengertian penggusuran atau pengadaan lahan dalam Perpres No. 30 Tahun 2015 adalah kegiatan menyediakan tanah dengan cara memberi ganti kerugian yang layak dan adil kepada pihak yang berhak. Pihak yang Berhak adalah pihak yang menguasai atau memiliki Objek Pengadaan Tanah, yaitu tanah, ruang atas tanah dan bawah tanah, bangunan, tanaman, benda yang berkaitan dengan tanah, atau lainnya yang dapat dinilai.Adapun beberapa faktor yang menyebabkan terjadinya penggusuran antara lain:

1. Kebijakan pembangunan yang lebih mengarah pada pembangunan investasi.

2. Peraturan pemerintah ataupun peraturan daerah tidak berpihak kepada rakyat miskin.

3. Tidak adanya koordinasi antar lembaga kepemerintahan

4. Ketimpangan sosial yang cukup tinggi

5. Sengketa lahan

\section{Penyebab Konflik Penggusuran Lahan}

Faktor-faktor penyebab terjadinya konflik penggusuran lahan adalah masyarakat merasa dirugikan karena pada umumnya berita pemberitahuan penggusuran mendadak dan tanpa ada komunikasi sebelumnya. Beberapa kasus dalam penggusuran ini warga tidak diajak bicara, dimana menurut masyarakat pemerintah melalui Satpol PP langsung menggusur lahannya sehari sejak surat penggusuran diterima. Sehingga warga masyarakat tidak mempersiapkan kepidahannya maupun memikirkan kemana mereka akan pindah. Tidak sedikit warga masyarakat yang pada awalnya memang sangat menggantungkan hidupnya pada lahan yang terkena penggusuran.

Proses pembangunan yang melibatkan penggusuran selama ini banyak mengakibatkan kerugian bagi korban penggusuran. Baik dari segi sosial maupun ekonomi, karena korban penggusuran kehilangan tempat tinggal yang selama ini menjadi tempat bernaung dan bersosialisasi dengan lingkungan sekitarnya. Namun bagi sebagian orang penggusuran dianggap sebagai berkah karena jumlah uang ganti rugi yang besar.

Dalam prakteknya, korban seringkali kembali ke lahan atau pindah ke lahan lain. Sebagai contoh warga Bongkaran Jakarta Pusat, yang digusur paksa oleh Pemprov DKI dan PT. Kereta Api Indonesia pada awal Agustus 2014, pindah ke bantaran kali tidak jauh dari lokasi penggusuran. Contoh lain yaitu warga Papanggo yang digusur paksa oleh Pemprov DKI yang keliru mengidentifikasi penggusuran, pasca penggusuran warga beralih ke kolong tol dan hingga saat ini tinggal kembali di lahan penggusuran. Hal tersebut menunjukkan bahwa penggusuran paksa bukanlah solusi untuk penataan kota, keindahan ataupun ketertiban. Masyarakat miskin yang tidak memiliki sumber daya untuk membeli atau menyewa rumah layak akan selalu melakukan berbagai cara untuk memiliki tempat tinggal, tidak peduli seberapa tidak layakkah rumah tersebut. Permasalahan penggusuran lahan oleh PT KAI ini juga menyebabkan warga RW 12 Manggarai, Jakarta Selatan mau tak mau harus siap menghadapi penggusuran yang dilakukan oleh PT Kereta Api Indonesia (PT KAI). Penggusuran tersebut dilakukan oleh PT KAI sebagai upaya untuk membebaskan lahan yang rencananya akan dibangun double double track (DDT) Manggarai-Bandara Soekarno Hatta. Namun warga Manggarai menilai PT KAI tidak transparan dalam hal anggaran pelaksanana, perizinan, master plan, amdal, serta penyusunan studi kelayakan biaya tanah secara keseluruhan.

Komentar Umum PBB No. 7 tentang Hak Atas Tempat Tinggal yang Layak: Penggusuran Paksa (Pasal 11 ayat (1) Kovensi Internasional Hak-Hak Ekonomi, Sosial, dan Budaya menyatakan bahwa dalam hal penggusuran tidak bisa dihindari maka pemerintah harus memastikan bahwa solusi 
alternatif telah disediakan Tanpa solusi alternatif maka pemerintah dilarang untuk melakukan penggusuran. Hingga saat ini belum banyak terdapat solusi alternatif yang disediakan oleh pemerintah ketika terjadi penggusuran. Penggusuran seringkali dilakukan secara paksa dan mengusir korban penggusuran tanpa solusi apa-apa. Seringkali korban penggusuran pasca penggusuran melakukan upaya sebagai berikut:

1. Kembali ke lahan tempat semula ia digusur ketika petugas Satpol PP sudah tidak berada di lokasi.

2. Pindah ke lahan lain yang terlantar atau bukan diperuntukkan untuk perumahan. Misalnya kolong tol, bantaran kali, dan sebagainya.

3. Menumpang di rumah keluarga untuk sementara.

4. Menyewa rumah di tempat lain.

5. Kembali ke kampung halaman dimana ia memiliki rumah ataupun keluarga untuk menumpang.

Beberapa penyebab terjadinya konflik pembebasan lahan dalam pembangunan tol Cisumdawu seluas 60,47 kilometer di Kecamatan Jatinangor Kabupaten Sudangan diantaranya tidak sesuainya harga penggantian ganti rugi yang diberikan pemerintah. Hal ini dirasakan oleh beberapa warga yang mempunyai tanah tepat di lingkar keluar tol Cisumdawu yang diberi harga 1,3 juta per meter. Penggantian hanya dihitung luas tanahnya saja padahal dalam tanah tersebut telah berdiri ruko sehingga pemilik tanah merasa dirugikan. Pada saat ditentukan nilai ganti rugi yang ditentukan pemerintah, warga masyarakat tidak diajak musyawarah. Pada saat terjadi penggusuran lahan, masyarakat merasa dirugikan karena lahan yang terkena tol terdapat lahan usaha yang menghidupi banyak orang. Di lokasi tersebut ada percetakan, beberapa toko dan ada juga bengkel yang mempekerjakan sejumlah pekerja. Nilai ekonomis dari penggusuran lahan tersebut menimbulkan dampak terhadap penghidupan masyarakat.
Namun ada juga warga yang terdampak pembangunan Tol Cisumdawu ini sudah siap pindah, disini warga sudah sepakat namun pembayaran belum dilaksanakan karena menunggu Mou perubahan harga lahan oleh Badan Usaha Jalan Tol (BUJT) dengan Lembaga Manajemen Aset Negara (LMAN).

\section{Upaya Preventif Konflik Penggusuran Lahan}

Dalam tulisan ini ditekankan pada upaya pencegahan atau upaya preventif terjadinya konflik dalam penggusuran lahan. Upaya preventif biasanya dilakukan kepada pihak yang belum atau rentan terhadap suatu masalah, menurut L. Abate (1985) Prevention atau pencegahan terdiri dari berbagai pendekatan, prosedur dan metode yang dibuat untuk meningkatkan kompetensi interpersonal seseorang dan fungsinya sebagai individu dalam kelompok maupun masyarakat.

Selanjutnya menurut L. Abate (1985) bagian besar program preventif yang efektif memiliki karakteristik sebagai berikut:

1. Fokus terhadap pemahaman mengenai resiko dan masalah dari perilaku yang ingin dicegah dalam kelompok sasaran

2. Desain untuk merubah "life trajectory" dari kelompok sasaran, dengan menyediakan pilihan dan kesempatan dalam jangka panjang yang sebelumnya tidak tersedia.

3. Kesempatan untuk mempelajari keterampilan hidup baru yang dapat membantu partisipan untuk menghadapi stress dengan lebih efektif dengan dukungan sosial yang ada.

4. Fokus dalam menguatkan dukungan dasar dari keluarga, komunitas atau lingkungan sekolah.

5. Koleksi dari penelitian yang memiliki kualitas yang baik menjadi bukti dalam keefektivitasaan dokumen.

Sedangkan menurut Oktavia (2013) upaya preventif adalah sebuah usaha yang 
dilakukan individu dalam mencegah terjadinya sesuatu yang tidak diinginkan. Preventif secara etimologi berasal dari bahasa latin pravenire yang artinya datang sebelum/antisipasi/mencegah untuk tidak terjadi sesuatu. Dalam pengertian yang luas preventif diartikan sebagai upaya secara sengaja dilakukan untuk mencegah terjadinya gangguan, kerusakan, atau kerugian bagi seseorang. Dengan demikian upaya preventif adalah tindakan yang dilakukan sebelum sesuatu terjadi. Hal tersebut dilakukan karena sesuatu tersebut merupakan hal yang dapat merusak ataupun merugikan.

\section{Upaya-upaya penggusuran akibat} adanya pembangunan yang tidak menyebabkan terjadinya konflik dapat dilihat dalam beberapa penanganan yang dilakukan di Kali Code Yogyakarta misalnya. Dalam penataan Kali Code tidak dilakukan penggusuran warga yang ada di bantaran sungai. Namun dalam hal ini warga mampu melakukan penataan secara mandiri dan membuat bantaran kali lebih bersih, indah, dan aman untuk dihuni. Pemberdayaan berhasil mengubah paradigma masyarakat bagaimana menghargai lingkungan dan sungai. Budaya membuang sampah ke kali kemudian bisa diubah, budaya menjadi ditonjolkan dan menjadi identitas warga Kali Code. Penataan yang cukup memberikan dampak adalah dengan mengubah rumah menghadap ke sungai sehingga tidak menjadi tempat sampah" dan dijaga kebersihannya. Penataan juga berhasil mempertahankan bantaran dan tidak mengganggu aliran sungai dan menyediakan fasilitas-fasilitas untuk kebutuhan warga Kali Code. Penataanpun akhirnya mampu melampaui peraturan perundang-undangan yang melarang adanya pemukiman di sempadan sungai.

Namun bila penggusuran lahan ini memang harus dilakukan karena adanya program pembangunan seperti pembuatan jalan, bendungan dan fasilitas publik lainnya maka beberapa upaya yang dapat dilakukan untuk mencegah terjadinya konflik penggusuran lahan diantaranya:

\section{Sosialisasi}

Sosialisasi perencanaan pembangunan yang akan dilaksanakan sangat pentung bagi masayrakat yang terkena dampak pembangunan. Sosialisasi ini berisi apa saja manfaat dari pembangunan yang akan dilaksanakan dan apa rencana pemerintah terhadap masyarakat yang terdampak dari pembangunan tersebut. Pada masyarakat yang kurang bisa menerima pembangunan ini sosialisasi dilakukan secara silaturahmi kepada tokoh-tokoh masyarakat, pemuka agama dan diharapkan dapat sampai informasinya pada masyarakat pada umumnya.

Beberapa kasus konflik penggusuran lahan ini diakibatkan tidak ada sosialisasi dulu pada masyarakat yang terkena dampak. Masyarakat biasanya cemas ketika dapat serombongan orang yang tiba-tiba mengukur lahan mereka tanpa tahu apa yang akan dilakukan pada lahan mereka.

Pada kasus penggusuran lahan untuk pembangunan tol Cisumdawu masyarakat merasa kurangnya sosialisasi dari pemerintah mengenai rencana pembangunan terutama yang melewati rumah penduduk di seksi 1 Cileunyi. Beroperasinya Tol Cisumdawu sangat diharapkan akan memperlancar konektivitas antara Jawa Barat bagian selatan menuju utara karena menghubungkan dua tol yang telah beroperasi yakni Tol Purbaleunyi dengan Tol Cikopo-Palimanan (Cipali). ToL Cisumdawu juga menjadi akses alternatif menuju Bandara Internasional Kertajati Majalengka.

\section{Mufakat}

Mufakat adalah adanya kesepakatan antara warga yang terkena dampak dengan pihak pemerintah dalam hal penggusuran lahan. Selama ini masyarakat banyak yang tidak diajak dialog dan bermusyawarah dalam sengketa penggusuran lahan. Apabila diadakan musyawarah untuf mufakat diharapkan konflik tidak akan terjadi. Masyarakat tidak merasa dirugikan dengan adanya pembangunan dan pemerintah tidak mempunyai hambatan dalam pelaksanaan pembangunan.

\section{Ganti rugi}

Ganti rugi berupa kompensasi berupa uang terhadap tanah yang dibebaskan 
seringkali menimbulkan konflik. Hal ini dapat dicegah dengan penggantian ganti rugi yang sesuai dengan nilai lahan yang digusur sehingga masyarakat dengan senang hati meninggalkan lahannya dan menerima kompensasi yang layak.

Hal ini mengacu pada setiap orang berhak atas perlindungan diri pribadi, keluarga, kehormatan, martabat dan hak miliknya sesuai ketentuan Pasal 29 ayat (1), dan apabila sesuatu benda berdasarkan ketentuan hukum demi kepentingan umum harus dimusnahkan atau tidak diberdayakan baik untuk selamanya maupun untuk sementara waktu, maka hal itu dilakukan dengan mengganti kerugian sesuai dengan ketentuan peraturan perundang-undangan kecuali ditentukan lain, Pasal 37 ayat (2) Undang-Undang Nomor 39 Tahun 1999 tentang Hak Asasi Manusia,"

\section{Partisipasi masyarakat}

Dalam berbagai aktivitas pembangunan, setiap warga negara memiliki hak untuk terlibat aktif. Hak partisipasi tersebut pun telah dijamin oleh konstitusi sebagimana termaktub dalam Pasal $28 \mathrm{C}$ ayat (3) UUD 1945 yang menyatakan: Setiap orang berhak untuk memajukan dirinya dalam memperjuangkan haknya secara kolektif untuk membangun masyarakat, bangsa, dan negaranya. Artinya, dalam berbagai aktivitas pembangunan mulai dari tahap perencanaan, pemanfaatan, sampai pengawasan memerlukan peran aktif masyarakat sebagai kontrol sosial, dan citizen partisipation is citizen power. Karena setiap pembangunan yang dilakukan oleh pemerintah, masyarakatlah yang nantinya akan merasakan dampaknya baik positif maupun negatif.

Apabila masyarakat dilibatkan mulai dari tahap perencanaan, pelaksanaan dan evaluasi, masyarakat akan merasa memiliki program pembangunan sehingga akan mendukung penuh terhadap pelaksanaan pembangunan. Partisipasi ini dapat juga berupa pelibatan masyarakat dalam hal pekerjaan yang dilaksanakan dalam pembangunan tersebut, dalam arti setiap proyek yang dilakukan harus melibatkan pekerja lokal sebagai tenaga kerja yang utama.

Setiap kegiatan pembangunan haruslah bersifat pareto superior (membangun menguntungkan segala pihak terutama masyarakat), bukan pareto optimal (membangun mengorbankan orang lain). Tujuan utama pembangunan adalah untuk mencapai kemakmuran dan kesejahteraan warga negara Indonesia. Nilai-nilai penting dari partisipasi masyarakat dalam pembangunan adalah untuk; pertama, peran masyarakat adalah sebagai suatu strategi. Maksudnya, peran serta masyarakat merupakan strategi untuk mendapatkan dukungan masyarakat (public support).

\section{Relokasi}

Relokasi merupakan pemindahan tempat warga yang terkena dampak ke tempat baru yang layak. Yang menjadi permasalahan adalah tempat baru yang menjadi relokasi warga biasanya masih minim dari fasilitas-fasilitas umum yang ada di tempat yang sebelumnya. Agar tidak muncul konflik maka pemerintah seharusnya memperhatikan kelayakan dan dapat meningkatkan kesejahteraan masyarakatnya.

\section{KESIMPULAN DAN SARAN}

\section{Kesimpulan}

Berdasarkan pembahasan dimuka, maka dapat disimpulkan beberapa hal berikut ini:

a. Penyebab konflik penggusuran lahan pada umumnya disebabkan masyarakat merasa tidak puas dan merasa dirugikan dengan adanya pengusuran lahan mereka. Masyarakat mengharapkan agar dalam proses penggusuran pemerintah melakukan perlindungan prosedural, tanpa intimidasi dan kekerasan serta mengerahkan aparat secara proposional. 


\begin{tabular}{|l|l|l|l|r} 
& & & & ISSN: $2339-0042(\mathrm{p})$ \\
Share: Social Work Jurnal & VOLUME: 10 & NOMOR: 1 & HALAMAN: $109-117$ & $\begin{array}{l}\text { ISSN: } 2528-1577(e) \\
\text { DOI: } 10.24198 / \text { share.v10i1.26896 }\end{array}$ \\
\hline
\end{tabular}

b. Upaya-upaya preventif perlu dilakukan untuk mencegah konflik ketika terjadi penggusuran lahan yaitu dengan melakukan sosialisasi kegiatan pembangunan yang dilaksanakan, mufakat untuk mencapai kesepakatan antara masyarakat dengan pemerintah dalam pembangunan, penggantian ganti rugi yang layak dan tidak merugikan masyarakat, partisipasi mayarakat dalam kegiatan pembangunan mulai dari perencanaan, pelaksanaan dan evaluasi dan relokasi yang layak bagi masyarakat yang terkena dampak dan bertujuan kesejahteraan masyakatnya.

\section{Rekomendasi}

Rekomendasi dalam upaya preventif konflik penggusuran lahan ini perlu dilakukan oleh pemerintah dalam bentuk kebijakan yang berpihak pada masyarakat. Upaya pencegahan ini layak dipertimbangkan sebelum terjadinya konflik dan menimbulkan masalah sosial yang lebih besar. Komunikasi dan sosialisasi kepada masyarakat terdampak pembangunan perlu dilakukan jauh-jauh hari sebelum pelaksanaan pembangunan infrastruktur dilakukan. Partisipasi dan kepercayaan masyarakat setempat dalam pembangunan perlu diupayakan agar menjaga kesinambungan hasil-hasil pembangunan.

\section{PUSTAKA}

Al Ghifari. LBH Jakarta. 2018.

Alston, L. J., Libecap, G. D., \& Mueller, B. (1999). A model of rural conflict: Violence and land reform policy in Brazil. Environment and Development Economics.

https://doi.org/10.1017/S1355770X9900 0121

Arifin, B. (2006). Transaction cost analysis of upstream-downstream relations in watershed services: Lessons from community-based forestry management in Sumatra, Indonesia. Quarterly Journal of International Agriculture.

Berner, E. (2000). Poverty alleviation and the eviction of the poorest: Towards urban land reform in the Philippines. International Journal of Urban and Regional Research. https://doi.org/10.1111/14682427.00265

Datta, S. K. (2006). Property Right, Risk of Eviction and Degradation of Common Pool Resources. IASCP 2006 Conference.

Gewald, J.-B., Alexander, J., McGregor, J., \& Ranger, T. (2001). Violence and Memory: One Hundred Years in the "Dark Forests" of Matabeleland. African Studies Review. https://doi.org/10.2307/525620

Gibson, J. L. (2005). Overcoming Land Injustices: An Experimental Investigation Into the Justice and Injustice of Land Squatting in South Africa. E Spring Meeting of the Working Group on African Political Economy, University of California at Los Angeles, May 13-14, 2005, Los Angeles, $C A$.

Joshi, P. C. (1974). Land Reform And Agrarian Change In India And Pakistan Since 1947: II. The Journal of Peasant Studies. https://doi.org/10.1080/0306615740843 7894

Kothari, M. (2005). Economic, Social and Cultural Rights - Report of the Special Rapporteur on adequate housing as a component of the right to an adequate standard of living. United Nations Economic and Social Council.

L Abate.1985. Primary and Secondary Prevention Strategies. London: Sage Publications.

Lamb, V., \& Middleton, C. (2015). "I saw the impact of the [Economic Land Concession] on the men." Notes towards a feminist political ecology of land access in Southeast Asia. Land Grabbing, Conflict and Agrarian-environmental Transformations: Perspectives from East and Southeast Asia. 


\begin{tabular}{|c|c|c|c|c|}
\hline Share: Social Work Jurnal & VOLUME: 10 & NOMOR: 1 & HALAMAN: $109-117$ & $\begin{array}{c}\text { ISSN: 2339-0042 (p) } \\
\text { ISSN: 2528-1577 (e) } \\
\text { DOI: 10.24198/share.v10i1.26896 }\end{array}$ \\
\hline
\end{tabular}

Mahadevia, D., Mishra, A., \& Joseph, Y. (2017). Ecology vs housing and the land rights movement in Guwahati. In Economic and Political Weekly.

Massoi, L. W. (2015). Land coflicts and the livelihood of Pastoral Maasai Women in Kilosa district of Morogoro, Tanzania. Afrika Focus. https://doi.org/10.21825/af.v28i2.4869

Mueller, B., Alston, L. J., \& Libecap, G. D. (1999). A Model of Rural Conflict: Violence and Land Reform Policy in Brazil. Environment and Development Economics.

Mwesigye, F., \& Matsumoto, T. (2016). The Effect of Population Pressure and Internal Migration on Land Conflicts: Implications for Agricultural Productivity in Uganda. World Development. https://doi.org/10.1016/j.worlddev.2015 .10 .042

Mwesigye, F. (2014). Rural-rural Migration and Land Conflicts: Implications on Agricultural Productivity in Uganda. 2014 World Bank Conference on Land and Poverty".

Naughton, L. (1993). Conservation versus artisanal gold mining in Corcovado National Park, Costa Rica: land use conflicts at neotropical widerness frontiers. Yearbook - Conference of Latin Americanist Geographers.

Nulhaqim, Soni Akhmad., Irfan, Maulana., Harding, Diana., Jatnika, Dyana Chusnulita. (2017). Konflik Sosial Di Kampung Nelayan : Studi Kasus di Pantai Utara Kota Cirebon, Jawa Barat. Jurnal Sosiokonsepsia Kementerian Sosial Republik Indonesia Volume 6 Nomor 2 Januari-April 2017.

Oktavia, Yuni. 2013. Promotof Preventif Kuratif, Rehabilitatif, http://yunivia88.blogsopt.co.ic/2013/05) promotofpreventifkuratifrehabilitatif.html diakses tanggal 11 November 2019.

Putra, Bagus Ani. (2013). Peran kearifan lokal dalam resolusi konflik keyakinan beragama di Jawa Timur. Jurnal
Masyarakat, Kebudayaan dan Politik Volume 26 Nomor 1 Tahun 2013, Halaman 1-14.

Sarin, M. (2006). Tribal rights and conservation practice in India's forests. Development.

Sirima, A. (2016). The Social and Economic Impacts of Ruaha National Park Expansion. Open Journal of Social Sciences.

https://doi.org/10.4236/jss.2016.46001

Tati, G. (2008). Immigrants and coastal artisan fishing in a context of constrained spatial expansion in the City of PointeNoire (Congo-Brazzaville). EspacePopulations-Societes. https://doi.org/10.4000/eps.2337

Tusinski, G. O. (2015). The spectral city: Cultural belonging, urban space, and post-conflict reconstruction in Dili, TimorLeste. In ProQuest Dissertations and Theses.

USAID Land Tenure and Property Rights. (2011). Property rights and resource governance: Cameroon. USAID Country Profile.

Weinstein, L. (2014). The durable slum: Dharavi and the right to stay put in globalizing Mumbai. In The Durable Slum: Dharavi and the Right to Stay Put in Globalizing Mumbai.

www.sipuu.setkab.go.id diakes 11 November 2019.

Yang, X., Zhao, H., \& Ho, P. (2017). Mininginduced displacement and resettlement in China: A study covering 27 villages in 6 provinces. Resources Policy. https://doi.org/10.1016/j.resourpol.2017 .07 .001 